\title{
高酸素化天然シクロヘキサン誘導体の化学
}

\author{
市原 耿民 Akıtami ICHIHARA \\ 坂 村 貞 雄 Sadao SAKAMURA \\ 北海道大学農学部農芸化学科
}

天然物化学分野に执いて研究対象として與味ある生理 活性新化合物は, 各種クロマトグラフィー, 分析機器の 発達により近年非常な速度で增加している.もちろん， これらの大部分は従来からよく知られている骨格を有す るものが占めているのは当然であるが，しばしばその骨 格が特異なものであったり，骨格は普通のものでも，分 子内にひずみのかかった小員環を含むすのなどが数多く 見いだされている．面白いことに，このような特異な化 合物がいったん見つけられると，その化合物と構造的に， または生合成的に何らかの関連を有する化合物が時を同 じくして異なった研究グループによって見つけられる傾 向があり, その分野の研究が一段と加速されることはめ ずらしくない，その一例として，高度に酸素化された天 然シクロヘキサン誘導体がある(1) (図 1).

この範儔に属するものとしては, この解説でとりあげ<smiles>CC1=C(O)C(=O)C2OC2C1=O</smiles><smiles>CC1=C(O)C(O)C2OC2C1=O</smiles><smiles>O=CC1=CC(=O)C2OC2C1=O</smiles>

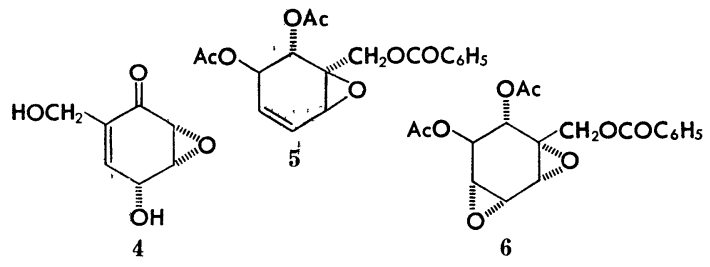

図 1 亮度に酸素化された天然シクロヘキサン 誘導体
る terreic acid $(\mathbf{1})^{(2)}$, terremutin $(2)^{(3)}$, phyllostine $(3)^{(4)}$, epoxydon $(4)^{(5)}$, senepoxyde $(5)^{(6)}$, crotepoxide (6) (7)のほか, 古くから知られているシキミ酸(8), キナ 酸などがある. 天然有機化合物は, 抗生物質, ビタミ ン，ホルモンなどのように生理活性に基礎をおくもの， chemotaxonomy を背景にするもの, テルペン, アセ卜 ゲニンなど生合成の立場からするるのなどに分類できる が, 化学構造による場合が最も一般的で, 高度に酸素化 された天然シクロへキサン誘導体もこの方式に従ったも のである. したがって, 生理活性についても，抗菌性， 抗がえ性をはじめ, 植物毒としての葉の萎调, 生長抑制 作用のほか，発根促進作用を示すものなど，幅広い様々 な活性を示している．また，生合成ではシキミ酸経路， polyketide 経路を経るものなど，一様ではない，しか し，合成的な見地からみると，これらの化合物はすべて 炭素数 7 個の基本骨格からなり，またいずれも六員環内 にエポキシ環を 1 個または 2 個を含む特異な化合物であ るため，同一原料からきわめて似かよった経路で合成し らると考えられる.ここでは, これら一群の化合物の構 造, 合成, 生合成, 生理活性などの研究について, とく にその研究の背景, 考方方, 方法などに焦点をしぼって まとめた。

\section{1. エポキシシクロヘキサン環の構造的特徵}

天然有機化合物の中でも比較的炭素数の少ない:一群で あるシクロへキサン誘導体は, 容易にその構造を確定で きると考えられやすいが，実際にはそれほど簡単ではな 
い. crotepoxide(6)はこの誘導体の X線解析により決定され(7a)，また terremutin(2) の相対配置は合成に より初めて明らかになった ${ }^{(9)}$ 。この ことは, シクロヘキサン誘導体の構 造解析に NMR が有力な手段となっ ているにもかかわらず，エポキシ環 の導入により特殊なひずみを生じ, 特異な立体配座をとるため, 従来の 経験的な NMR だけのデータではそ の解析が充分でなかったためと理解される.

Terreic $\operatorname{acid}(1)$ の構造(2) はUV, IR で検討されたほ か, このものをフッ化ホウ素の存在下, 無水酶酸と処理 することにより新化合物 $2,3,4,5,6$-pentaacetoxytaluene、に転換し，これが 3,5,6-trihydroxytoluquinone の還元的アセチル化により合成されたものと一致したこ とまた 2,3-epoxy-1,4-naphthoquinone の NMR ス ペクトルとの比較などにより，5,6-epoxy-3-hydroxytoluquinone(1) であることが決定された。 なお，絶対 配置は後に Miller により, terremutin(2) が脱水素に より terreic acid に転換されることから 2 のエポキシ 環と同一の立体配置をとることが判明した ${ }^{(3)}$.

ところで, terremutin(2) の構造に対して最初 7 式が 提出されていた ${ }^{(3)}$. 絶対配置は， $\alpha, \beta$-エポキシおよび<smiles>CC1=C(O)C(O)C2OC2C1=O</smiles>

$\alpha, \beta$-シクロプロピルケトン類に掦出されている逆オク タント則を適用することにより決定された．２には2つ のコンホマー 2a，2b が可能である（図 2). それぞれ を別の方向から眺めた $\mathbf{2}$ c， $2 \mathrm{~d}$ により明らかなよらに， 前者は O-axial, 後者は O-equatorial の立体配座をと っているが，2a では C-4，C-5 の置換基が staggered conformation をとるため相互作用が少ないこと，また エポキシ筥を形成する。電子とカルボニル基の $\pi$ 電子と の間に共鳴が可能であることから， $\mathbf{2} \mathbf{a}$ が安定と推定さ れる. この立体配座で $318 \mathrm{~nm}$ の $n \longrightarrow \pi *$ 還移に対し て逆オタタント則を適用すると，2ẹk示したようにCD で負の領域にエポキシ環があり実測值もこの予想に一
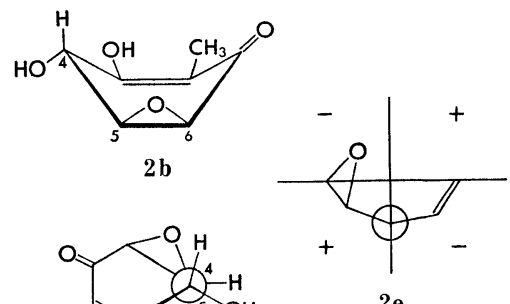

$2 \mathrm{e}$

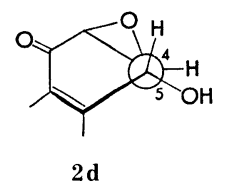

$2 \mathrm{c}$

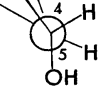

$2 d$

致した，相対配座については，NMR より 4-H，5-H， 6-H ととれぞれ $1 \mathrm{~Hz}$ 程度の結合常数を示し, 前者につ いてはモデルからエポキシ環と $\mathrm{OH}$ が cis(7) の場合に Karplus 式より算出される数値とよく一致するとしてい るが，4-H と6-H との間の long range coupling に ついては言及していない，その後, Read ら(9)によって terremutin の 2 つの立体異性体 2, 7 が合成されるに および，両者の NMR の詳細な検討により， 2 には 4H，6-H がゆがんだW字型の構造をとるため, これに起 因する long range coupling がみられるとした. 異性 体 7 では, epoxydon などと同様にこの型の結合常数は みられない，このことから訂正された構造 (2) は，その 反応物の NMR に打いても矛盾なく説明されるので最終 的に確定された，

な拉ここで述べたエポキシケトンが 0-axial(2a)の

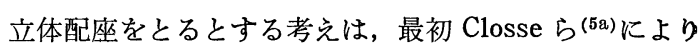
epoxydon の立体構造について論じられ，さらに Read らが terremutin について詳細に検討したものであるが， 筆者らの得た多数のエポキシケトン類も例外なく 0 axial 配座を持つことが確かめられている. また, terremutin の 4-H, 6-H 間のゆがんだ W字構造にもとづ く long range coupling についても, 筆者らの epoxydon 類縁体 ${ }^{(10)}$, senepoxyde ${ }^{(11)}$, crotepoxide ${ }^{(12 a)}$ の合 成中間体に適用され，その立体構造の解明にきわめて有 力な根拠となった。

Phyllostine(3) は, 赤クローバーの黒葉枯病菌の代謝 産物の 1 つとして epoxydon (4, phyllosinol) とともに 単離された化合物であり, 分光学的手法のほか, epoxydon phyllostine に化学変換したものが天然の phyllostine と混融しても融点降下を示さないことから，そ の構造を 3 と決定したものである( ${ }^{(4)}$. Closse ら ${ }^{(58)}$ が抗 
腫瘍性物質探索の過程で Phoma S 1019 菌の代謝産物と して見いだしていた epoxydon は，筆者ら(5b)の phyl1osinol と NMR, CD を比較することにより，同一物で あることが明らかとなった，構造はUV, IR, NMRなど により 4 式が提出された。 あちろん，4には terremutin (2)にみられる 4-H，6-H 間にW字則にもとづく long range coupling は観測されない, 立体配座については, terremutin の場合と同様，エポキシ環とカルボニル基 が共鳴可能な O-axial をとるとし，この立体配座で 4 は $\mathrm{CD}$ で $341 \mathrm{~nm}$ の $n \rightarrow \pi^{*}$ 遷移に正の吸収が期待され るが, 実測もこの予想に合致するので4の絶対配置が与 えられた。

Uvaria catcarpa はマダガスカルの高原に広く分布す るバンレイシ科に属するつる状の植物で, この実はフラ ンスにおいてからて民間薬として使用されてきた，この 実より単離した senepoxyde(5) の構造 ${ }^{(6)}$ は多くの誘導 体の IR, NMR により決定され, 特に立体化学について はいくつかの誘導体に Horeau 法を適用したり，CD を 測定することにより決定している.この 5 と近縁のもの に crotepoxide(6) がある. これは, Kupchan ら ${ }^{(7 a) か ゙ ~}$ 天然物より抗がん性物質を探索する一連の研究過程でエ チオピアで採集した植物, Croton macrostachys の実よ り単離したもので, 高橋ら ${ }^{(7 b)}$ が Piper futokazura Sieb (フウトウカジラ）より単離したfutoxide と同一物であ る. crotepoxide(6) ならびにこの誘導体の分光学的デ 一タと, 最終的にはこのものをヨウ化水素酸で処理して 得られる iodohydrin(8)のX線回析により, その構造 が確定した.

\section{2. 化学合成に用いた方法}

天然物化学を志す者にとって興味ある研究対象の一つ に, 菌類および動植物の生体内で起こっている生合成が ある.これらは複雑な構造を持つ化合物, テルペン, ス テロイド，アルカロイド，アセトゲニンなどをいとる簡 単に生成し, しかもこれらの天然物は特定の官能基を特 定の位置に保持して沏り, また不斉炭素を有するるのに ついては光学活性体であることより, 生体内で位置なら びに立体特異的に反応が進行していることを示している. さらに，これらの生合成はきわめて緩和な条件下で営ま れるものであり, 実験室での化学反応のように高温, 高圧, 強酸, 強塩基などの過激な条件を必要としない. 現在で
は，生合成に抢ける特異性はすべて醭素の触媒作用によ るものと理解され, 酵素モデルの研究も活発に行なわれ ている. 天然物を対象とする化学合成の際, 生合成研究 は多くの示唆を与えてくれ，これら生合成機構に似せ た経路で化学的に天然物を合成する方法を biogenetic synthesis(13) といい，盛えに利用されている．筆者らの 用いた隣接基効果 ${ }^{(14)}$ はすでに分子内触媒作用として知 られており，酵素類似様反応の一分野である.

この効果は, 分子内に存在する隣接基が, 特定の反応 中心と結合するか試薬を配位させるかしてその反応を加 速するため, 特定の官能基のみが反応にあずかるもので ある．換言すれば，位置選択的反応が起こり，またその 遷移状態が立体効果を生み出するのであれば, 立体選択 的反応が期待される. 広く天然有機化合物の中で，特に 複雑な官能基を多数有する化合物において，しばしば隣 接基効果がそれらの構造研究の過程で観察されている.

筆者らは一連の天然シクロヘキサン誘導体の合成 ${ }^{(15)}$ に 扔いて, この隣接基効果を合成経路の一部にとり入れる ことにより，位置選択的反応を行なわせることに成功し た.

\section{Terreic $\operatorname{acid}(1), T$ Terremutin(2) の合成}

Terreic acid, terremutin はいずれも Read らによ りその合成が達成されたが，彼らのこの種の合成に拈け る功績は新しいエポキシ化法を開発したことである，従 来までのキノン類のエポキシ化は塩基条件下で過酸化水 素により行なら方法であったが，2-hydroxy-3-methyl1,4-benzoquinone のようなベンゾキノン類をこの条件 でェポキシ化しても，生成物が強い塩基により直ちに分 解されてしまらため成功していない，新しいエポキシ化 法は過ホウ素酸ナトリウム $\left(\mathrm{NaBO}_{3}\right)$ を使用するるの(16) で，あらかじめ $\mathrm{pH}$ を 9 付近に調製したこの試薬をメタ ノールに溶解した試料に加えると反応は迅速（1１0 分 くらい）に起こり，たとえば terreic $\operatorname{acid}(\mathbf{1})$ が得られ る.この際, キノンの二重結合のらちのどちらかがエポ キシ化され，2つともエポキシ化されることはない.

さらに, Aspergillus terreus より単離された代謝産 物 terremutin(2) の合成が行なわれ，2 は Miller によ り先に提出された構造式 (7) を改める結果となった ${ }^{(9)}$. すなわち， 1 を 2 当量の水素化ホウ菜ナトリウムで還元 すると,フェノール性水酸基の隣接基効果のため 2 個の カルボニル基のうち 4 位のもののみが還元され, しかも 


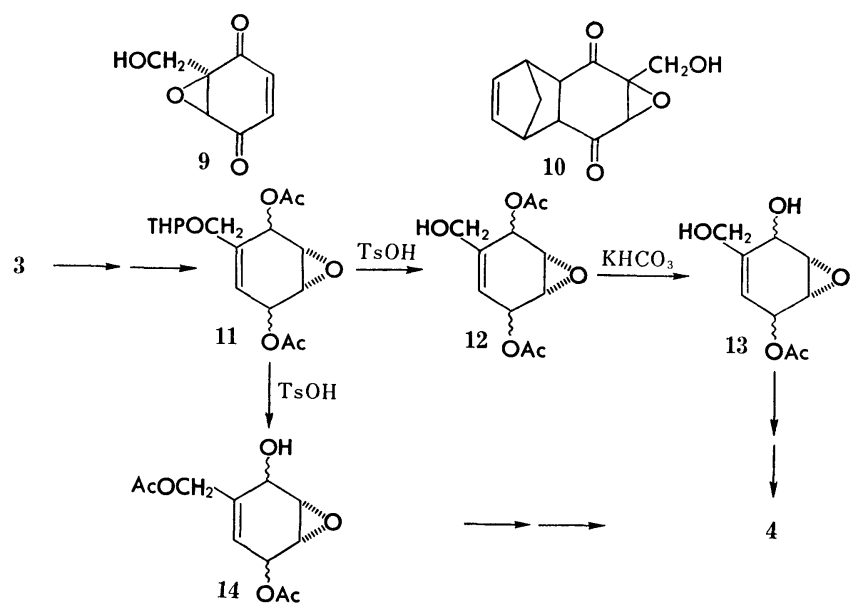

たのち (13) 数段階で, または 11 の酸処理で隣接基効果のためアシル 基転位を起こした 14 を得ることに より合成された。

\section{Epoxydon 関連化合物の合成}

一般に, キノン類にエポキシ環を 導入する方法としては, 前述の過ホ ウ素酸ナトリウムのほか過酸化水素 水，有機過酸などが使われているが, いずれの場合も生成物の不安定性の ため収量が悪く，しかもェポキシ化 の方向に選択性がみられない。これ らの点を解決するために, キノン類にジメチルフルベン を付加させ，得られた付加物をエポキシ化したのち熱分 解してキノンエポキシド（15）を，またエポキシ化物を さらに還元したのち熱分解して $\alpha$-エポキシシクロヘキ セノン（16）を合成することに成功した(10)（図 3），最 初の計画ではジメチルフルベンの代りにシクロペンタジ エンを用いたが，すでに同様の方法で Alder らがキノ ンエポキシドをきわめて好収量で得ているので，その方 法に従い実験を進めた。しかし，逆 Diels-Alder 反応 である熱分解を $420^{\circ} \mathrm{C}$ といら高温で行ならため，収量が 悪く実用的でなかった．筆者らはこの点を考慮して前述 のような方法に変え，ほぼ定量的な収量で目的物を得る ことができた．このようにして得られたエポキシドン類 縁体の生理活性については後述する.

\section{Senepoxyde (5), Crotepoxide (6) の合成}

図 4 に筆者らの行なった senepoxyde (5) (11), crotepoxide (6) ${ }^{(12 a)}$ の立体選択的合成経路を示した. この合 成の特徵は, 前述したジメチルフルベンによるキノンの 二重結合の保護が単にこの目的のために有効であるばか

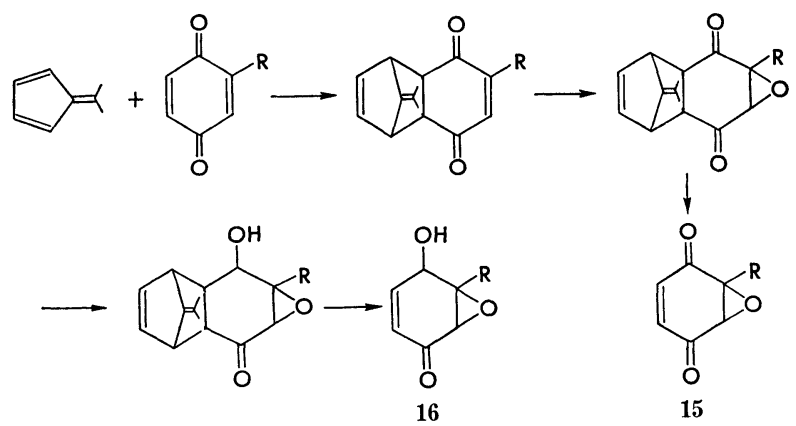

16

図 3 エポキシキノン (15)，エポキシシクロへキセノン(16)の一般合成法った.

りでなく，その後の還元反応に拈い て立体選択的に還元を行なうために も必須のものとなっている。また， 引き続き行なっているアシル化の段 階でも, 直接相当するキノン誘導体 を用いるより，反応を安定な形で進 めることができ，逆 Diels-Alder 反 応のような一見過激な反応を含むと はいえきわめて効果的な手段とな

図 3 エポキシキノン(15), エポキシシクロヘキセノン (16)の一般合成法った.

Vol. 14, No. 2 

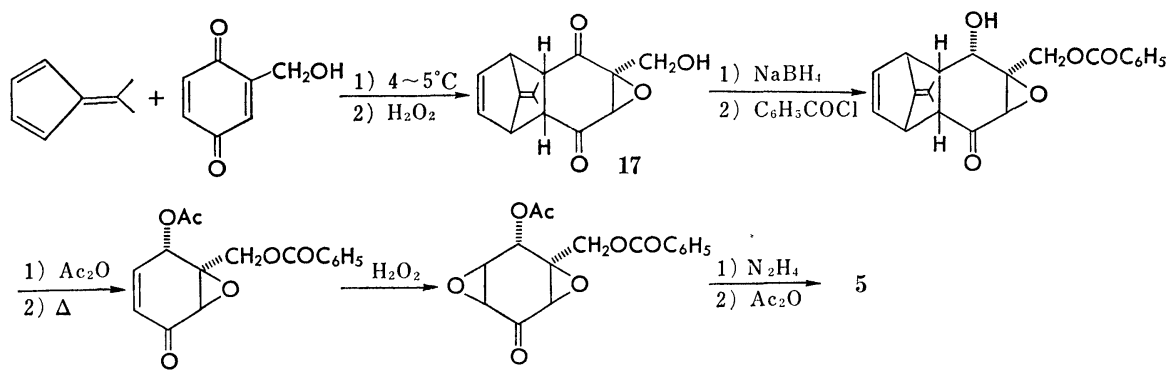

Crotepoxide $(6) の$ 合成

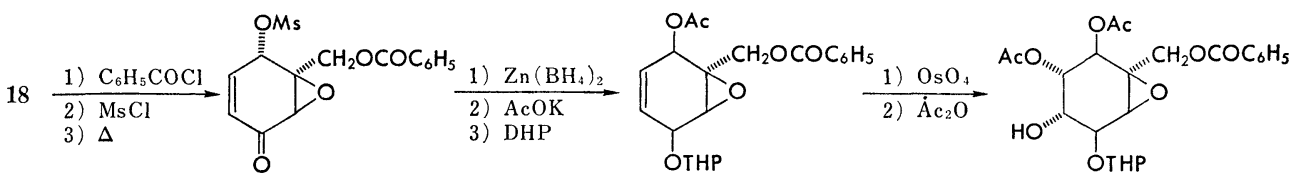

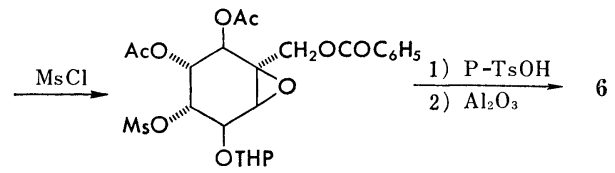

White らのCrotepoxıdeの合成

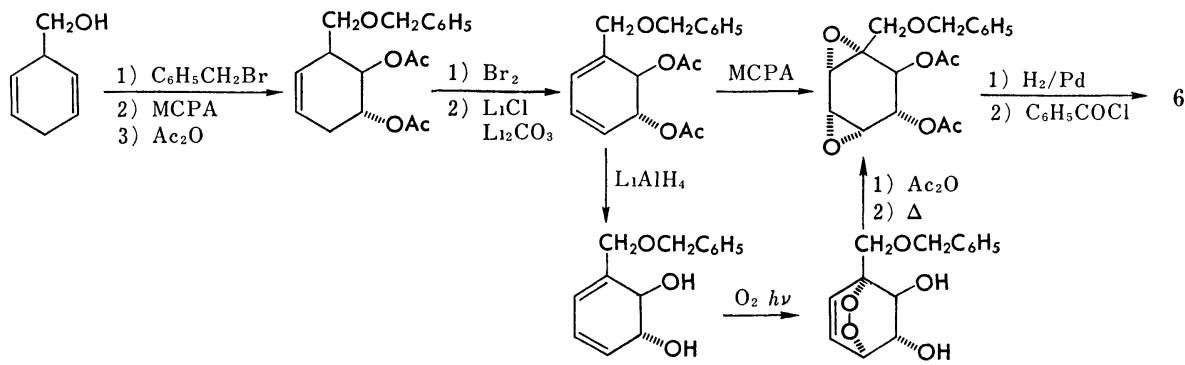

図 4 Senepoxyde(5), $\operatorname{Crotepoxide}(6)$ の合成

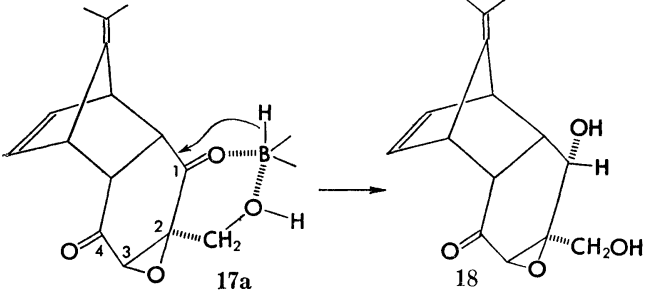

さらに, ジケトン 17 の還元では, C-1 ケトンのみが還 元されており, 隣接ヒドロキシメチル基が立体障害とし て僖くとすると逆の結果であるが，実際には17a のよう な隣接基効果を受けるため, 位置選択的に 18 を与えて いる. 図 4 には最近オレゴン大学の White ら(12b)により行なわれた $d l$ crotepoxide(6)の合成を併記した. 光化学反応を巧みに利用した点が注
目される。

\section{3. 生 合 成 と 代 謝}

Phyllosticta sp. は epoxydon(4), phyllostine(3), 3-chlorogentisyl alcohol(23) のほか, 6-methylsalicylic $\operatorname{acid}(\mathbf{1 9})$, gentisyl alcohol(20) を培地中に生成するこ とから，4 が polyketide 経路によって生合成されるこ とを暗示した ${ }^{(18)}$. Read ら ${ }^{(19)}$ はすでに, ${ }^{14} \mathrm{C}$-䣫酸と ${ }^{18} \mathrm{O}$ 標識化合物を用いた Asp. terreus の培養により, terreic acid(1) が polypetide 経路で生合成され，エポキ

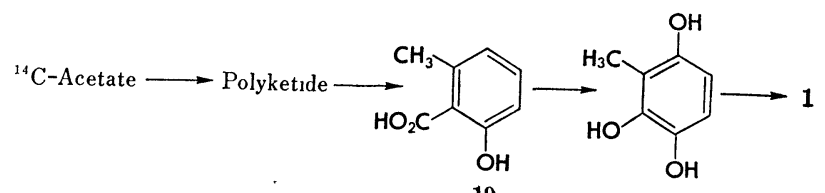




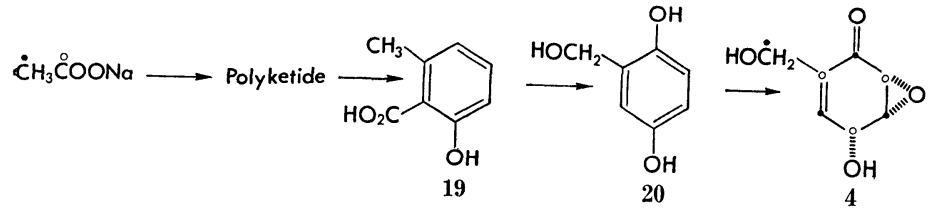<smiles>CC[C@H](O)COC=O</smiles>

図 5 Phyllosticta sp. による epoxydon(4) の生合成と代謝

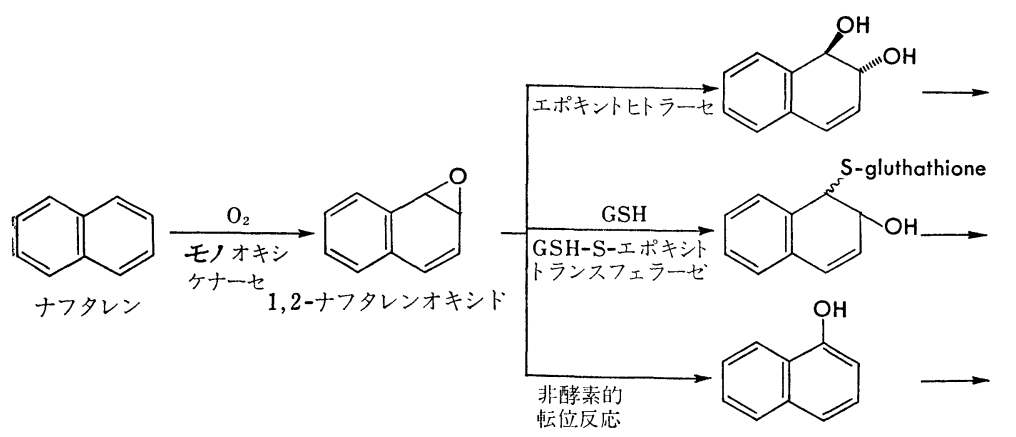

図 6 動物におけるナフタレンの代謝 ${ }^{(21)}$

シ環の酸素は空気中の $\mathrm{O}_{2}$ 由来であることを証明した. 筆者らは，1-13 C-酢酸执よび $2{ }^{13} \mathrm{C}$ 一酢酸をとり达ませた 4 の ${ }^{13} \mathrm{C}$ NMR 実験ならびに ${ }^{14} \mathrm{C}$-gentisyl alcohol の 4 へのとり込み結果から，その後の代謝を含めて 4 の生合 成経路を図 5 のように確立した ${ }^{(20)}$ ３８４同様な経 路上で生合成されることは，1 の生合成からも容易に類 推される. しかし, 植物起源の関連物質についてはシキ ミ酸経路に従う生合成経路も証明されている.

エポキシ環の生成は，4，3，1 特よび terremutin(2) ルおいてフェノール化合物を前駆体として空気中の酸素 で行なわれることは疑いないまた，芳香族炭化水素の 代謝, 解毒機構研究の中で芳香環のエポキシド (arene oxide）が重要な中間体であることが図 6 のごとく示さ れ,ナフタレンは動物の肝ミクロソーム画分に存在する
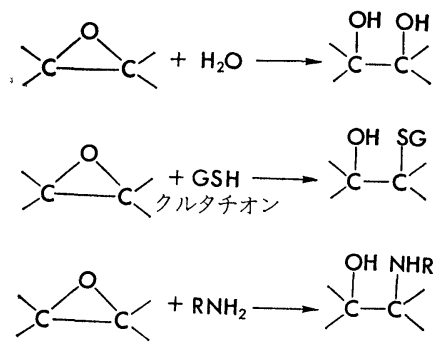

mixed function oxygenase によっ て 1,2-オキシドを与える(21). 酵素 による $\mathrm{O}_{2}$ の活性化は “oxene” の生 成を考えると理解しやすい(左下図) 生じたエポキシ環は, 一般式(A)(B) に従って水和, $\mathrm{SH}$ 化合物, アミン, アンモニアなどによる酵素的あるい は非酵素的親核反応によって代謝さ れる(22). 動物臓器には(A)反応を触媒 するエポキシヒドラーゼと，B反応 を触媒する $\mathrm{GS}^{\prime} \mathrm{H}-\mathrm{S}^{\prime}$ 一エポキシトラ ンスフェラーゼが見いだされ，それ 以降の薬物代謝系之相俟って解毒の 役割を果たしている， C反応を触媒 する酵素系は明らかでないとしても， アミン,アミノ酸, タンパク質, 核 酸との非酵素的反応が充分に考学ら れる、1,2-ナフタレンオキシドか ら 1ーナフトールの生成は, 化合物 25 から 26, 27 の生成の場合と同様酸素の移動を伴ら結果 となり, “oxygen walk”の例である(23).<smiles>CC1=CC2(C)OC2(C)C=C1</smiles>

25
26<smiles>Cc1ccc(C)c(O)c1</smiles>

27
一方，植物に拈けるエポキシ化の反応は， cyclodiene insecticide（ドリン剂）を用いたエンドウの芽生におい ての実験で,アルドリン（28）をジェルドリン（29）に

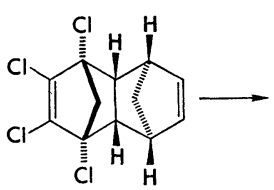

28

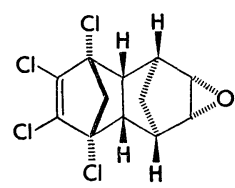

29
変える酵素系がミクロソーム画分に存在することによっ て示された ${ }^{(24)}$. エポキシ化とエポキシドの代謝は糸状 菌によるトランスーエポキシサクシネートの睽酵生産に みられ，エポキシサクシネート・サイクル(25) (図 7 ) の 提案がなされ, tartarate epoxidase の酵素レベルでの 研究に発展した. このようにして生体内に生成したエポ キシドは,ひずみのかかったエチレンオキシドの部分構 
造を持ち，反応性に富んでいる．

Phyllosticta sp. は、エポキシド

(3，4）を生ずるとともに，3-chlo-
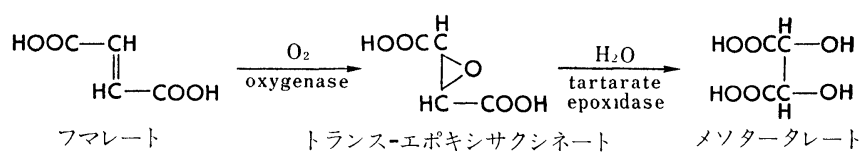
rogentisyl alcohol(23) のほか微量

図 7 エポキシサクシネート・サイクル

成分として 21，22，24 を与兄ることから，23 の生成機 構に興味が持たれた(図 5 ). これらの化合物は, エポキ シ環に対するアニオンの攻撃によって始をる反応で説明 される. 事実, 23は馬鈴薯惹汁に含まれる塩素イオンに よって4から無菌的に生成されることが判明し，4 の生 成が軸となった 1 つの含塩素化合物の生成機構が提案さ れた(20). 微生物の産生する他の含塩素化合物がエポキシ ドを中間体として生成されるか否かは, 個々の場合で検 討されねばならないとしても，一つの可能性を示するの といえよう。

\section{4. 生理活性の多樣性と反応機構}

前揭の天然シクロヘキサン誘導体には, crotepoxide (6, 抗がん性), epoxydon (4, 抗腫瘍性, 細胞毒性), terreic acid (1, 抗菌性) の示す顕著な生理活性のほか, 4, 3 には植物に対する萎调誘導や発根促進, 抗菌性が 認められ, 総じて $\alpha, \beta$-不飽和カルボニル基とエポキシ 環のいずれかの活性基が生理活性発現に寄与しているも のとみることができる．また，両者が相加的に作用する こともあろう.

\section{$\boldsymbol{\alpha}, \boldsymbol{\beta}$-不飽和ヶトン由来の活性}

$\alpha, \beta$-不飽和ケトン構造を持つキノン類は, 古くより 植物, 昆虫, 微生物から多数発見され, 構造に対する興 味とともに様々な生理活性が指摘された(26)。ことに節 足動物の beetles はキノン化合物を含み, 時に外敵を防 ぐため有毒キノンを発射し，小麦を污染して被害を与兄 る. 污染小麦粉は生じた 2,6-dimethoxybenzoquinone （30）のためピンクに着色し，また 30 は発がん性である<smiles>COC1=CC(=O)C=C(OC)C1=O</smiles><smiles>CC1=CC(=O)CC(C)(C)C1</smiles>

32<smiles>O=C1C=CC(=O)c2c(O)cccc21</smiles>

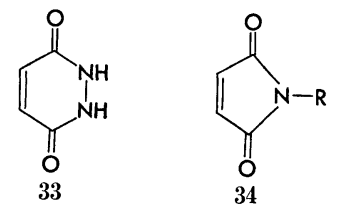<smiles>[R]C(=O)C=C([R])[R6]</smiles>

図 $8 \alpha, \beta$-不飽和ケトンと $\mathrm{SH}$ 基との反応

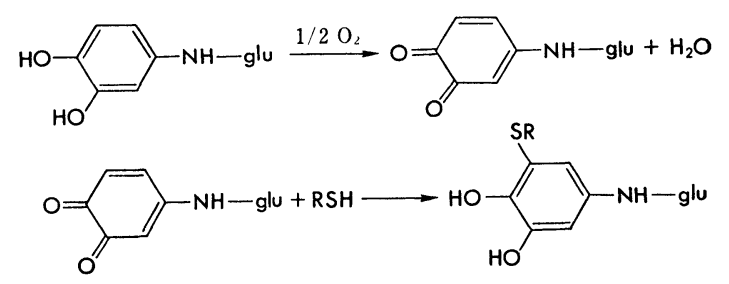

図 9 o-ジフェノールによる酵素阻害の一例 $\mathrm{glu}=$ グルタミン酸残基

らといわれる. しかし, 30 を小麦粉に加えると, 存在 するグルタチオンと付加反応を行ない, 結果的にグルタ チオンの示すドウの品質低下を防止するため, 小麦粉改 良剂としての効果もある. ユグロン (31) はクルミの外 果皮, 葉中に含まれ, 植物に対する他感作用, 魚毒, た むし治療作用が古くから知られていた. そのほか, isophorone(32), maleic hydrazide(33), $\mathrm{N}$-置換maleimide (34), shodomycin などの生理活性物質は, 酵素を含め た生体活性部位の $\mathrm{SH}$ 基と直接反応 ${ }^{(27)}$ して活性現象を現 わす一方, 活性物質があらかじめ SH 試薬（たとえばグ ルタチオン）と反応してしまえば化合物本来の活性を減 少する結果になり，一種の解毒と見なされる，両者の反 応機構は, 近似的ないしは類型的に図 8 のごとく理解す ることができる.

動植物界に広く分布する テコラーゼによって ー-キノン（一種の $\alpha, \beta$-不飽和ケト ン）を生ずることはよく知られ，植物の病原菌に対する 抵抗性之関連する. キノコ(Agaricus bisporus)の菌槢か ら見いだされた $\gamma$-L-glutamy1-3,4-benzoquinone ${ }^{(28,29)}$ はミトコンドリヤの $\mathrm{SH}$ 酵素 (コハク酸脱水素酵素, キ サンチン脱水素酵素など）を阻害し，ひいては呼吸を減 少させ, 胞子形成と関係している. この物質の生成, 酵 素阻害は図 9 に示したようである. 赤クローバー茎割病 の病原菌 Kabatiella caulivora に侵された赤クローバ 一茎は 0 -ジフェノール含量が高まり, 菌に対する抵抗 
性が認められる. 事実, 罹病菱中から単離された trans および cis-clovamides(35)(30),ささには phaseolic acid<smiles>O=C(/C=C/c1ccc(O)c(O)c1)NC(Cc1ccc(O)c(O)c1)C(=O)O</smiles>

35

はそれぞれフェノラーゼやペルオキシダーゼの基質とな り，それらの生成物は同菌の発芽を完全に阻止する(31). この生理活性も，生成した されるるのとみられる.

\section{エポキシ環由来の活性}

前述の生理活性シクロヘキサン誘導体には, 分子内に $\alpha, \beta$-不飽和ケトン基とエポキシ環とを同時に持つるの, エポキシ環だけを持つるのの両者の場合がある. エポキ シ環のみに活性を帰することのできると考えられる典型 的化合物を，エチレンオキシド（殺菌剂）とトランスー サクシネート(25) (Fusarium sp. により生成されるア 一モンドの植物毒）にみることができる．抗がん性物質 triptolide, tripdiolide $(36)^{(32)}$ の活性は, 水酸基が関与
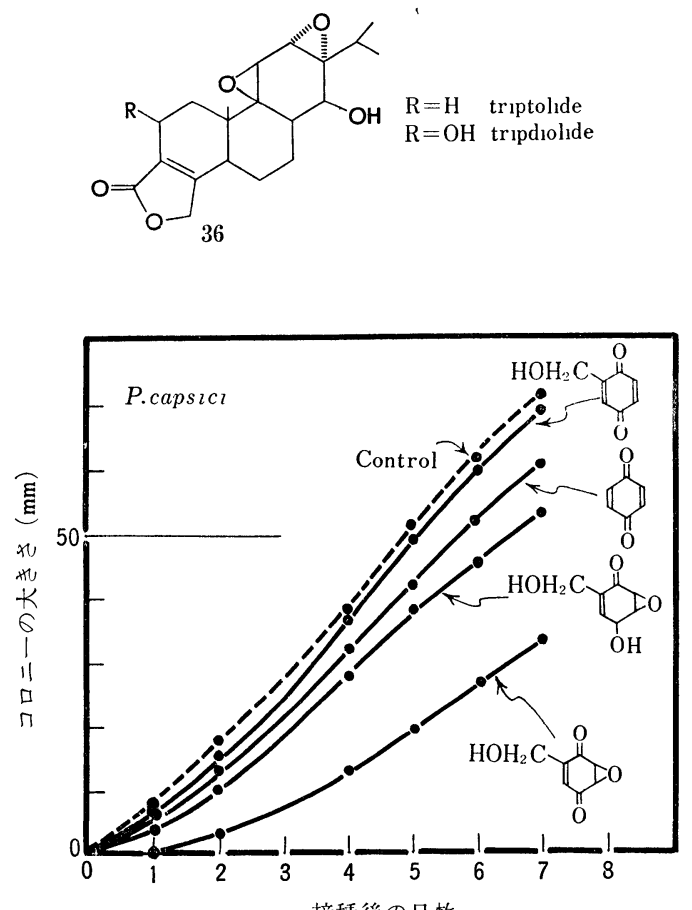

図 10 Phytophthora capsici に対する epoxydon 類縁体の抗菌性 ${ }^{(36)}$ 各物質の濃度は $2 \times 10^{-4} \mathrm{M}$<smiles>CCC1=CC(=O)C2OC2C1=O</smiles><smiles>CC12OC1C(=O)C=CC2=O</smiles><smiles>CCCOC1C2C(=O)C=CC(=O)C12</smiles>

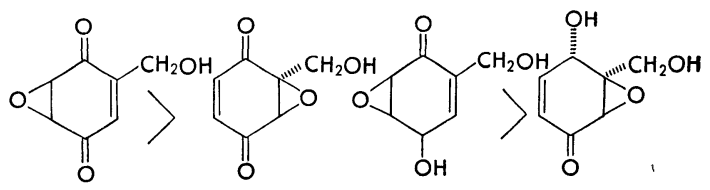

図 11 Epoxydon 類縁体の生理活性の相互比較

したエポキシ環開裂反応が関係している. 生理活性エポ キシドの多くは置換基が非対称で，1個のエポキシド化 合物は 2 つ生成物を与光, 溶液の塩基性，中性と酸性 条件下では両者の生成比を大きく異にし，極性基などの 置換は開裂方向を左右する ${ }^{(33)}$.

生体に妨ける個々のエポキシドは溶液の条件と構造に 規定された一定の類似反応を行ならことが考奌られる. epoxydon(4) とよる小豆 cuttings の発根促進は, シス テイン添加により 4 の促進活性が失われるととるに反応 生成物を与える ${ }^{(34)}$. 生成物を知るためのモデル実験と して，4をエチルメルカプタンおよびシステアミンと緩 和な条件下で処理したところ，それぞれ 37 と 38 の生 成物を与えた ${ }^{(35)}$ 。これらの事実は，エポキシ環が SH 基,<smiles>CCSC1C(=O)[C@H](C=O)[C@H](SCC)[C@H](O)[C@H]1O</smiles>

37<smiles>CCOc1cc(CO)c2c(c1)SCCN2</smiles>

38
アミン, アミノ基を含むタンパク質や核酸と反応し，活 性に関わるであろらことを示唆するるのである．分子内 に $\alpha, \beta$-不飽和ケトンとエポキシ環を同時に有する物質 は，キノンとキノンエポキシドの抗菌性にみられるよ らに（図 10），エポキシ環導入によって活性増加がみら れる(36).

さらに, 合成 epoxydon 類縁体のイネ幼苗の伸長, 小 豆 cuttings の発根促進などの㥀物生理活性, ならびに 抗菌性について共通していえることは，図11 に示した 通りで，大略次のようにまとめることができる(37).

1）エポキシ環は三置換より二置換化合物.

2）アルキル基としてヒドロキシメチル基よりメチル 基. 
3) enone $(\underline{\underline{I}}=-)$ より enedione $(\underline{\underline{O}}=\underline{\text { III }})$ 構造の ほうが活性が強い。

しかし，骨格構造を異にした化合物間の比較は，化合 物の全体の形, 溶解性, 細胞の膜透過などが関係し, 構 造と生物活性の相関を複雑にしている.

以上とりあげた高度に酸素化されたシクロヘキサン誘 導体の汪かにも, 近縁の生理活性物質, panepoxydon ${ }^{(38)}$, LL-Z 2120(39)などが単離されており，合成対象としても 興味の持てるものである。 また，エポキシドの生合成， 代謝, 生物活性機構など, 物質变化を中心に類型的基礎 覞念を見いだそうと大胆な論議を試みてみた。 今後，内 生エポキシドについては生合成，代謝の面から興味ある 知見が生まれるであろうし，外生エポキシドについては 㑑々の化合物の示す広範・多彩な生物活性と個別的反応, 代謝の解明をまって，統一的反応機構の生まれることが 望をれる。

\section{文献}

1) S.M. Kupchan, R J.Hemingway, P Coggon, A.T. McPhail \& G. A.Sim : J. Amer. Chem. Soc., 90, 2982 (1968).

2) J.C. Sheehan, W. B. Lawson \& R. J. Gaul : $\imath$ bid., 80, 5536 (1958).

3) M.W. Miller : Tetrahedron, 24, 4839 (1968).

4) S. Sakamura, J.Ito \& R. Sakai : Agr. Biol.Chem., 34, $153(1970) ; 35,105$ (1971).

5a) A.Closse, R. Mauli \& H. P. Sigg : Helv.Chim. Acta, 49, 204 (1966).

5b) S. Sakamura, H. Niki, Y. Obata, R. Sakai \& T. Matsumoto : Agr. Biol.Chem., 33, 698 (1969).

6) F. Hollands, D. Becher, J. Gaudemer, J. Polonsky \& N. Ricrochi : Tetrahedron, 24, 1633 (1968).

7a) S. M. Kupchan, R. J. Hemingway \& R. M. Smith $: J$. Org. Chem., 34, 3898 (1969).

7b) S. Takahashi : Chem. Pharm. Bull., 18, 199 (1970).

8) シキミ酸の化学については総説がある. B. A. Bohm : Chem. Rev., 65, 435 (1965).

9) G. Read \& V.M. Ruiz: J.Chem. Soc. (C), 1945(1970).

10) A. Ichihara, M. Kobayashi, K. Oda \& S. Sakamura : Tetrahedron Letters, 4231 (1974).

11) A. Ichihara, K. Oda, M. Kobayashi \& S. Sakamura : ibid., 4235 (1974).

12a) K. Oda, A. Ichihara \& S. Sakamura : ibid., 3187 (1975).

12b) J.D. White 教授からの私信.

13）最近の総説として，たと爷ば E.E.van Tamelen：Acc. Chem. Res., 8, 152 (1975) ; 加藤忠弘, 熊沢 智: 有合 化, 33, 223 (1975).

14) B. Capon: Quart. Rev. (London), 19, 45 (1965); L.

15）市原耿民：農化，49， R27 (1975).

Goodman : Advan. Carbohydrate Chem., 22, 109(1967).

16) A. Rashid \& G. Read : J.Chem.Soc. (C), 1323(1967).
17) A.Ichihara, K. Oda \& S. Sakamura : Agr.Biol.Chem., 38, 163(1974) ; 35, 445 (1971) ; Tetrahedron Letters, 5105 (1972).

18) W.B. Turner : "Fungal Metabolites", Academic Press, 1971, p. 74.

19) G. Read, D. W. S. Westlake \& L.C.Vining : Canad. J. Biochem., 47, 1071 (1969).

20) K. Nabeta, A. Ichihara \& S. Sakamura: J.Chem. Soc. Chem. Commun., 814 (1973) ; Agr. Biol. Chem., 39, 409 (1975).

21）早川太郎, S. Udenfriend : 化学の領域, 28, 8 (1974); N. Kaubish, J.W. Daley \& D. M. Jerina : Brochemistry, 11, 3080 (1972).

22) W. B. Jakoby \& T. A.F jellstedt : "The Enzymes", 7, ed. by P. D. Boya, 199 (1972).

23) P.Y. Bruice, G. J. Kasperek \& T. C. Briuce : J. Amer. Chem., 95, 1673 (1973).

24) J. W. Earl \& I. R. Keennedy : Aust. J. Biol. Sci., 26, 341 (1973).

25) C. J. Mirocha : "Phytotoxing in Plant Enzymes", ed. by R.K.S. Wood, A. Ballio and A. Gramiti, Academic Press, 1972, p. 191.

26) R.H. Thompson : "Naturally Occurring Quinones", 2 nd ed., Academic Press, 1971, p. 93, 107, 221.

27) M.Friedman : "The Chemistry and Biochemistry of the Sulfhydryl Group in Amino Acids, Peptides and Proteins", Pergamon Press, Inc., Oxford, 1973, p. 428.

28) R.F. Weaver, K. V. Rajagopalan, P. Handler, P. Jeff, W. L. Byrne \& D. Rosenthal : Proc. Natl. Acad Sci., 67, 1050 (1970)

29) R.F.Weaver, K. V. Rajagopalan \& P.Handler : $J$. Biol. Chem., 246, 2015, 2010 (1971).

30) T. Yoshihara, H. Yoshikawa, S. Sakamura \& T. Sakuma : Agr. Biol. Chem., 38, 1107 (1974).

31) Y.Sakuma, T. Yoshihara \& S. Sakamura : Post Congress Osaka Symp. Phytopathology, 1974, p. 57.

32) S. M. Kupchan \& R. M. Schubert : Science, 185, 791 (1974).

33) R. E. Parker : Chem. Rev., 59, 737 (1959).

34) R. Sakai, R. Sato, H. Niki \& S. Sakamura : Plant \& Cell Physiol., 11, 907 (1970).

35) K. Nabeta, A. Ichihara, R. Sakai \& S. Sakamura : $J$. Biol. Chem., 36, 2261 (1972).

36) R.Sakai, R. Sato, J. Ito \& S.Sakamura : An. Phytopath. Soc. (Japan), 38, 290 (1972).

37) 酒井隆太郎, 小林牧生, 小田研悟, 市原耿民, 坂村貞雄 : 日本植物病理学会大会講演要旨予稿集, A20 (1974); 同 F 82 (1975).

38) Z. Kis, A. Closse, H. P. Sigg, L. Hruban \& G. Snatzke: Helv. Chim. Acta, 53, 1577 (1970).

39) D. B. Borders, P.Shu \& J.E. Lancaster : J. Amer. Chem. Soc., 94, 2540 (1972).

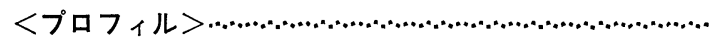

市原 耿民（Akitami Ichihara）昭和 9 年 6 月 4 日生<略 歴 $>$ 昭和 32 年北海道大学理学部化学科卒業 $/ 37$ 年同大学大学院 博士課程修了/同年同大学理学部助手 $/ 45$ 年同大学農学部農芸 化学科助教授，現在にいたる.この間，40〜 42年米国ショージ ア大学留学<研究テーマと抱負>生理活性物質の構造, 合成研 究に興味をもっているく趣味>スキー，音楽 